\title{
Assessment of Genetic Diversity in Five Nicaraguan Populations of Cedrela odorata L. (Meliaceae) using RAPD Markers
}

\author{
Arlen Tijerino*, Lourdes Callejas ${ }^{* *}$ and David A. Cerda-Granados ***
}

\section{Received: November 2015 / Accepted: March 2016}

The goal of this study was to assess the genetic diversity of Nicaraguan populations of Cedrela odorata using Random Amplified Polymorphic DNA (RAPD) markers. Thus, genomic DNA was isolated from leaf samples collected from ninety-two trees belonging to five Nicaraguan natural populations of C. odorata. The mean number of alleles per locus, effective number of alleles per locus, percentage of polymorphic loci, genetic diversity $\left(H_{e}\right)$ of Nei and diversity index $\left(H_{0}\right)$ of Shannon were estimated for each population assuming that the populations were in HardyWeinberg equilibrium. Total genetic diversity was partitioned in intrapopulational and interpopulational diversity using Nei's genetic differentiation $\left(G_{S T}\right)$ and through an Analysis of Molecular Variance (AMOVA). The $\square_{S T}$ matrix was used to construct a dendrogram by the neighbor-joining method. According to values of both $\mathrm{H}_{e}$ and $H_{o}$, Esquipulas (Deparment of Matagalpa) presented the lowest diversity level; while La Trinidad (Department of Estelí) showed the highest diversity level. Genetic differentiation was calculated obtaining a $G_{S T}$ value of $13.36 \%$. AMOVA also showed a similar differentiation value $\square_{S T}=13.81 \%$ ). Neighbour-joining dendrogram clustered the five populations in two groups, where the group formed by La Trinidad and El

Centro Nicaragüense de Investigación Agropecuaria (CINIA), Instituto Nacional de Tecnología Agropecuaria (INTA), Km 14.1 Carretera Norte, Managua, Nicaragua. E-mail: arlentijerino@gmail.com

** Universidad Nacional Autónoma de Nicaragua-León, Departamento de Biología, Facultad de Ciencias y Tecnología, Frente a la Iglesia La Merced, León, Nicaragua. E-mail: callejas811@gmail. com

*** Corresponding author. Universidad Nacional Autónoma de Nicaragua-León, Departamento de Biología, Facultad de Ciencias y Tecnología, Frente a la Iglesia La Merced, León, Nicaragua. E-mail: david.cerda@ct.unanleon.edu.ni 
Refugio (Department of Granada) presented the biggest differentiation. Correlation between genetic and geographical distances was not found.

Keywords: Cedrela odorata, Conservation, Genetic Diversity, Nicaragua, RAPD

\section{Abstract in Spanish:}

Evaluación de la diversidad genética de cinco poblaciones nicaragüenses de Cedrela odorata L. (Meliaceae) usando marcadores RAPDs

El propósito de este estudio fue evaluar la diversidad genética de poblaciones nicaragüenses de Cedrela odorata usando marcadores RAPD (ADN polimórfico amplificado al azar). Así, se aisló ADN genómico de hojas recolectadas de noventa y dos árboles pertenecientes a cinco poblaciones naturales de C. odorata. Se estimó para cada población el número de alelos por locus, número efectivo de alelos por locus, porcentaje de loci polimórficos, diversidad genética de Nei $\left(H_{e}\right)$ e índice de diversidad de Shannon $\left(H_{0}\right)$ asumiendo equilibrio de Hardy-Weinberg. La diversidad genética total fue particionada en diversidad intrapoblacional e interpoblacional usando la diferenciación genética de $\mathrm{Nei}\left(\mathrm{G}_{\mathrm{ST}}\right)$ y el Análisis de Varianza Molecular (AMOVA). La matriz $\square_{S T}$ se usó para construir un dendrograma con el método de neighbor-joining. De acuerdo a los valores de $H_{e}$ y $H_{o}$, la población de Esquipulas (Departamento de Matagalpa) presentó el nivel de diversidad genética más bajo; mientras que La Trinidad (Departamento de Estelí) mostró el nivel de diversidad más alto. La diferenciación genética fue calculada, obteniendo un $\mathrm{G}_{S T}=13.36 \%$. El análisis de varianza molecular (AMOVA) también mostró un valor de diferenciación similar $\left(\mathbb{Q}_{S T}=13.81 \%\right)$. El dendrograma neighbour-joining agrupó a las cinco poblaciones en dos grupos, donde el grupo formado por La Trinidad y El Refugio (departamento de Granada) presentó la diferenciación más grande. No se encontró correlación entre distancias genéticas y geográficas.

Palabras clave: Cedrela odorata, conservación, diversidad genética, Nicaragua, RAPD

\section{Introduction}

Cedrela odorata L. (Spanish cedar or cedro real) is a Neotropical tree belonging to the Meliaceae family found in the subtropical and tropical humid or seasonal dry forests (Holdridge, Poveda Alvarez \& Jiménez Madrigal, 1997; Cordero \& Boshier, 2003). Its natural range goes from latitude $26^{\circ} \mathrm{N}$ in the Pacific Coast of Mexico to latitude $28^{\circ}$ $\mathrm{S}$ in Argentina, being also present in the Caribbean islands (Niembro Rocas, 2002), and it has been introduced in Ethiopia, Fiji Islands, Ghana, Nigeria, Sierra Leone, Southern Florida, and Tanzania (Webb, Wood, \& Smith, 1980; Gezahgne, Coetzee, Wingfield, Wingfield \& Roux, 2004). It is an economically important timber tree producing high quality wood whose uses include construction, furniture and boat building (Niembro Rocas, 2002; Cordero \& Boshier, 2003). Its wood is resistant to 
attacks by fungi and insects, and its fragrance lasts for many years (Niembro Rocas, 2002). As a result, its natural populations have been severely reduced to the point that the species is now classified as "vulnerable" by the International Union for Conservation of Nature (Americas Regional Workshop, 1998), appearing in the CITES (Convention on International Trade of Endangered Species of Wild Fauna and Flora) Appendix III for the countries of Brazil, Guatemala, Colombia, Bolivia and Peru.

C. odorata is commonly found in Nicaragua with latitudes between 0 to 1200 m. It flowers from April to September, and it fruits from June to March (Pennington $\&$ Styles, 2001). This species, as in the rest of its natural range, has experienced a big population reduction in recent years. The size reduction of any population has a direct consequence in the reduction of its genetic variation (Frankham, Ballou $\&$ Briscoe, 2002). For this reason, it is necessary to detect and evaluate the genetic diversity of the populations in order to maintain their variation level and avoid extinction. There are no studies of population structure in Nicaraguan provenances of C. odorata. Thus, the conservation and plantation management of the species is done without this information. The only genetic data that exist are from phylogenetic studies carried out in Mesoamerica (Cavers, Navarro \& Lowe, 2003b) and its distribution range (Cavers et al., 2013), which can give us slight insights about how to manage the species in Nicaragua. Some research about the genetic structure of C. odorata has been carried out in Costa Rica (Gillies et al., 1997; Cavers, Navarro \& Lowe, 2003a) which can be taken as reference, since some Costa Rican populations could share the same kind of ecosystems and evolutionary history than the Nicaraguan populations.

The use of molecular techniques, especially the DNA based markers, has permitted access to any information in the genome. Among the molecular techniques that already exist, the Random Amplified Polymorphic DNA (RAPD) (Williams, Kubelik, Livak, Rafalski \& Tingey, 1990) is a very common technique used due to its simplicity and low cost. This technique is based in the random amplification of different DNA fragments with an only 10-nucleotides length primer that identify polymorphisms used as markers (Williams et al., 1990). RAPD has been successfully used by many researchers to assess the genetic diversity of several forestry species, e.g. C. odorata (Gillies et al., 1997), Swietenia macrophylla (Gillies et al., 1999), Prunus mahaleb (Jordano \& Godoy, 2000), Pinus oocarpa (Diaz, Muniz, \& Ferrer, 2001), and Pinus tecunumanii (Cerda Granados, 2007).

In this study, RAPD markers were used (i) to assess the genetic differentiation between populations and (ii) to estimate the levels of genetic diversity within populations of Nicaraguan C. odorata populations. This information will be useful in planning conservation and management programs of C. odorata in Nicaragua. 


\section{Materials and Methods}

\subsection{Plant Material}

Leaf samples were collected from 92 trees distributed in five Nicaraguan natural populations of C. odorata (Figure 1): (1) Volcán Casita (12 40' 27.0” N, $86^{\circ} 57^{\prime} 50.6^{\prime \prime}$ W) in Department of Chinandega, (2) Esquipulas (12 42' 19.5" N, 85० 47' 15.9" W) in Department of Matagalpa, (3) Masatepe (11 54' 12.1” N, 86 09' 20.7' W) in Department of Masaya, (4) El Refugio (11० $49^{\prime} 45.0^{\prime \prime} \mathrm{N}, 86^{\circ} 00^{\prime} 34.0^{\prime \prime} \mathrm{W}$ ) in Department of Granada and (5) La Trinidad (12०54'36.4” N, 86 14' 11.4" W) in Department of Estelí. The minimum distance between trees sampled was 100 $\mathrm{m}$. The number of trees from each population varied from 14 to 22. Field-collected material was dehydrated in silica gel during 3-5 days, grinded in lab conditions, and stored at $-20^{\circ} \mathrm{C}$

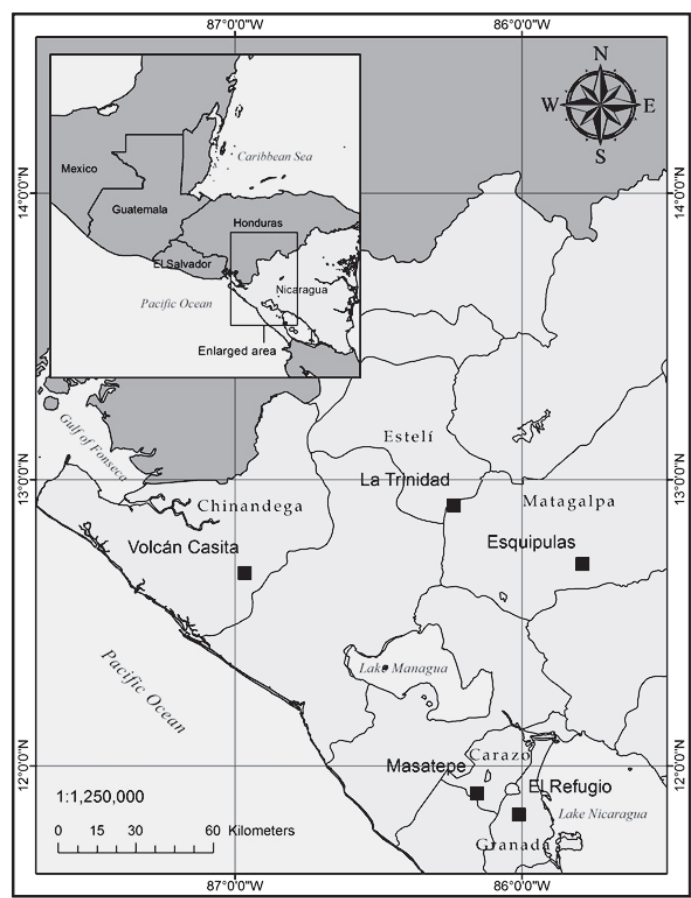

Figure 1. Nicaraguan populations of C. odorata () sampled for this study prior to DNA isolation.

\subsection{DNA Isolation}

The genomic DNA isolation was carried out as described by Möller, Bahnweg, Sandermann and Geiger (1992) with the following modifications: $2 \mu \mathrm{l}$ of I-mercaptoethanol 14.4 $\mathrm{M}$ was added to the extraction buffer, while proteinase $\mathrm{K}$ was not included during extraction. The first incubation was done at $65^{\circ} \mathrm{C}$ for $30 \mathrm{~min}$. We did a second extraction with chloroform:isomyl alcohol. The RNse treatment was carried out at the end of the procedure.

\subsection{RAPD amplification}

RAPD reactions were carried out in $25 \mu$ volumes containing 25 ng genomic DNA, 1X Buffer A (10 mM Tris- $\mathrm{HCl}$ ( $\mathrm{pH} 9.0), 50 \mathrm{mM} \mathrm{KCl}$, and $1.5 \mathrm{mM} \mathrm{MgCl}_{2}$ ), $0.2 \mu \mathrm{M}$ of primer, $200 \mu \mathrm{M}$ dNTPs and $1 \mathrm{U}$ of Taq polymerase (Fisher Scientific) (Williams et al. (1990) with slight modifications). Amplifications were performed in a termocycler 
(Amplitron ${ }^{\circledR}$ II Thermolyne) with the following program: $3 \mathrm{~min}$ at $92^{\circ} \mathrm{C}$ (initial denaturation); 45 cycles of $1 \mathrm{~min}$ at $92^{\circ} \mathrm{C}$ (denaturation), 2 min at $37^{\circ} \mathrm{C}$ (annealing), and $1 \mathrm{~min}$ at $72^{\circ} \mathrm{C}$ (extension); all followed by a final $8 \mathrm{~min}$ extension at $72^{\circ}$ C. Nine primers (OPF-01, OPG-10, OPN-09, OPR-07, OPS-18, OPT-08, OPU-16, UBC-228, and UBC-411) were selected from initial tests. Amplification products were separated by electrophoresis in $2.0 \%$ agarose gels with $1 \mathrm{X}$ TAE, stained with ethidium bromide, and then photographed under UV light.

\subsection{Data Analysis}

RAPD bands were scored as either present or absent in each DNA sample. Analysis was restricted to polymorphic bands, i.e. reliable scored bands with a frequency of less than $95 \%$ for the most common phenotype. The data file was investigated for nonrandom associations between individual pairs for bands using the correlation test of the SIMIT program (NTSYSpc 2.20 software) (Rohlf, 2005). The mean number of alleles per locus $(N)$, effective number of alleles per locus $\left(N_{e}\right)($ Kimura \& Crow, 1964), percentage of polymorphism over total bands $(P)$, the genetic diversity $\left(H_{e}\right)$ of Nei (1973) and the diversity index $\left(H_{0}\right)$ of Shannon (Lewontin, 1972) were estimated for each population assuming Hardy-Weinberg equilibrium. An analysis of simple correlation was carried out to detect possible relationships between diversity indexes. Total genetic diversity was partitioned in intrapopulational and interpopulational diversity using the Nei (1973)'s genetic diversity according to (Nei, 1987). Gene flow $(\mathrm{Nm})$ was calculated using the Nei (1987)'s coefficient of gene differentiation $\left(\mathrm{G}_{\mathrm{ST}}\right)$ according to McDermott and McDonald (1993). These analyses were done using the POPGENE ver. 1.32 program (Yeh \& Yang, 2000).

An Analysis Molecular of Variance (AMOVA) was carried out to obtain variance components within populations and between populations. Variance components were tested statistically by nonparametric permutational procedures using 1000 permutations. Genetic differentiation $\left(\square_{S T}\right)$ between pairs of the $C$. odorata populations, and levels of significance were also calculated. All analyses were performed using Arlequin 3.01 software (Excoffier, Laval \& Schneider, 2005). The Mantel test (Mantel, 1967) was used to estimate the possible association between the geographical distance matrix and the $\square_{S T}$ pairwise matrix using the MXCOMP program (NTSYSpc 2.20). Significance was determined using 1000 permutations.

The $\square_{S T}$ matrix was used to construct a dendrogram by the neighborjoining method (Saitou \& Nei, 1987) using the TREE program (NTSYSpc 2.20). A cophenetic value matrix was produced from the tree matrix using the $\mathrm{COPH}$ program (NTSYSpc 2.20). This matrix was then employed to check the goodness of fit of the cluster analysis by comparing it to the $\square_{S T}$ matrix (Sneath \& Sokal, 1973) using a Mantel test (Mantel, 1967) with 1000 permutations. 


\section{Results}

\subsection{RAPD Profile}

The number of bands per primer varied from 10 for primers OPT-08 and OPU-16 to 15 for primer UBC-228. The mean total bands per primer were 12 . Thus, a total of 108 bands with a molecular weight from $270 \mathrm{bp}$ to $3700 \mathrm{bp}$ were generated. Seventy eight bands were polymorphic (mean of 8.76 polymorphic bands per primer, ranging from 4 for OPN-09 to 14 for UBC-228).

\subsection{Genetic Diversity}

Genetic parameters calculated per population are presented in Table 1. N varied from 1.821 (Volcán Casita) to 1.910 (El Refugio) with an overall mean of 2.000. $\mathrm{N}_{e}$ varied from 1.489 (Masatepe) to 1.559 (La Trinidad) with an overall mean of 1.579. $P$ varied from $56.5 \%$ (La Trinidad) to $68.5 \%$ (Esquipulas) with an overall mean of $63.3 \% . H_{e}$ varied from 0.289 to 0.323 with an overall mean of $0.347 . H_{o}$ varied from 0.436 to 0.479 with an overall mean of 0.524 . A strong and significant correlation was found between $H_{e}$ and $H_{o}$ (Pearson, $r=0.999, P<0.0001$ ). Both diversity values showed that the least diverse population was Esquipulas, while the most diverse population was La Trinidad.

Table 1. Genetic variation parameters, genetic diversity of $\mathrm{Nei}\left(\mathrm{H}_{e}\right)$ and Shannon's information index $\left(H_{0}\right)$ for five Nicaraguan populations of C. odorata using RAPD markers.

\begin{tabular}{|l|c|c|c|c|c|}
\hline Population & $\mathbf{N}$ & $\mathrm{N}_{e}$ & $\mathbf{P}$ & $\mathbf{H}_{e}$ & $\mathbf{H}_{0}$ \\
\hline Volcán Casita & 1.821 & 1.499 & 59.3 & 0.294 & 0.440 \\
\hline Esquipulas & 1.872 & 1.490 & 68.5 & 0.289 & 0.436 \\
\hline Masatepe & 1.910 & 1.489 & 67.4 & 0.292 & 0.442 \\
\hline El Refugio & 1.910 & 1.541 & 64.8 & 0.316 & 0.474 \\
\hline La Trinidad & 1.885 & 1.559 & 56.5 & 0.323 & 0.479 \\
\hline All populations & 2.000 & 1.579 & 63.3 & 0.347 & 0.524
\end{tabular}

Note: $N$, number of alleles per locus; $N_{e}$, efective number of alleles per locus (Kimura $\&$ Crow, 1964); P, percentage of polymorphic loci over total bands; $H_{e}$, Nei (1973)'s gene diversity; $H_{o}$, Shannon's information index (Lewontin, 1972) over loci.

\subsection{Partitioning of Variation per Population}

Total genetic diversity $\left(H_{T}\right)$ was 0.350 , and the genetic diversity within populations $\left(H_{S}\right)$ was 0.303 . Thus, Nei (1993)'s genetic diversity index assigned a $13.3 \%\left(\mathrm{G}_{\mathrm{ST}}=\right.$ 0.133 ) of the total variation to the intrapopulational component, while $86.7 \%$ of the total variation was caused by differences between individuals within populations. $\mathrm{Nm}$ was 3.251 migrants per generation. 


\subsection{AMOVA Analysis}

In agreement with the $G_{S T}$ value, AMOVA (Table 2) found that most of the total variation was within populations $(86.19 \%)$ rather that between populations $\left(\square_{S T}\right.$ $=13.81 \%)$. This value was statistically significant $(\mathrm{P}<0.001)$. All pairwise $\square_{S T}$ values derived from AMOVA were statistically significant $(\mathrm{P}<0.001)$. The lowest genetic differentiation was found between Esquipulas and Masatepe $\left(\square_{S T}=0.062\right)$, while the highest differentiation was present between Volcán Casita and La Trinidad $\left(\square_{S T}=0.241\right)$. There was no correlation between genetic and geographical distances. This shows that Nicaraguan populations of C. odorata do not follow the isolation by distance model.

Table 2. AMOVA analysis in five Nicaraguan populations of C. odorata using RAPD markers.

\begin{tabular}{|c|c|c|c|c|c|}
\hline Source of variation & d.f. & Sum of squares & $\begin{array}{c}\text { Components of } \\
\text { variance }\end{array}$ & $\begin{array}{c}\text { Percentage of } \\
\text { variation }\end{array}$ & Ф statistic \\
\hline Between populations & 4 & 209.855 & 2.13930 & $13.81^{*}$ & $\Phi_{\text {ST }}=0.1381$ \\
\hline Within populations & 87 & 1161.591 & 13.35162 & $86.19^{*}$ & \\
\hline Total & 91 & 1371.446 & 15.49092 & & \\
\hline * $\mathrm{P}<0.001$ & & & & & \\
\hline
\end{tabular}

Significance test after 1000 permutations.

\subsection{Phylogenetic Relationships}

The dendrogram constructed with the $\square_{S T}$ pairwise matrix (Figure 2) shows the formation of two clusters. One group formed by the populations of Volcán Casita, Esquipulas and Masatepe and the other group by the remaining populations, El Refugio and La Trinidad. The dendrogram obtained was consistent with the $\square_{S T}$ pairwise matrix as demonstrated with correlation coefficient between the $\square_{S T}$ pairwise matrix and the cophenetic matrix from the dendrogram (Mantel test, $\mathrm{r}=0.990, \mathrm{P}=$ 0.018).

Figure 2. Neighbour-joining analysis showing the genetic relationships of five populations of C. odorata based in $\square_{S T}$ pairwise matrix generated by RAPD markers. The coefficient of cophenetic correlation was $r=0.99$

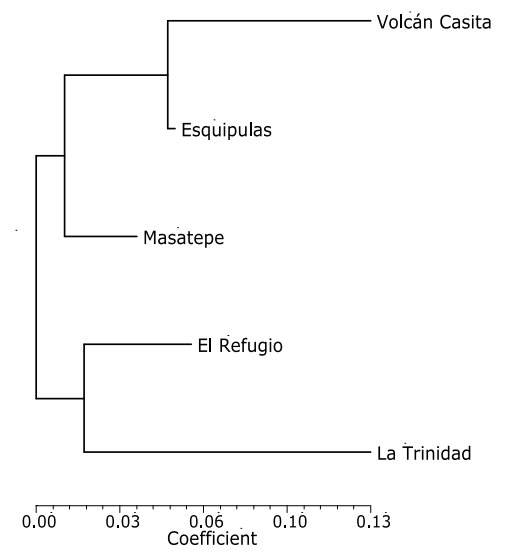




\section{Discussion}

The number of polymorphic bands (78) obtained in the present study is within the range that Nybom and Bartish (2000) recommended to have reliable RAPD data. Overall levels of genetic diversity $\left(P=63.3 \%, H_{T}=0.350\right)$ are higher than the mean of plant species $\left(H_{\mathrm{POP}}=0.214\right)$ reported by Nybom and Bartish (2000) and are comparable to other dicotyledonous tree species, e.g., Swietenia macrophylla (Gillies et al., 1999). They are also similar to values reported for other species of the Cedrela genus, such as Cedrela balansae in Northwestern Argentina using other molecular markers (expected heterozygosity $=0.643$ for SSR, and $P=60.47 \%$ and expected heterozygosity $=0.222$ for AFLP) (Soldati, Fornes, Van Zonneveld, Thomas $\&$ Zelener, 2013) and for C. odorata in Mesoamerica $\left(P=93.8 \%, H_{T}=0.34\right.$ (Gilles et al., 1997); $P=84.8 \%, H_{T}=0.27$ (Cavers et al., 2003a)), and Peru ( $P=98.8 \%$, $H_{T}=0.22$ (de la Torre, López, Yglesias \& Cornelius, 2008)). The same general trend was found with the Shannon index, such as the findings in two Mexican red oaks, Quercus affinis $(P=54.98 \%$, Shannon Index $=0.242)$ and Quercus laurina $(P=$ $55.19 \%$, Shannon Index $=0.249$ ) using RAPD markers (González-Rodríguez, Arias \& Oyama, 2005).

$G_{S T}(0.133)$ and $\square_{S T}(0.138)$ values presented in the current study were lower than the mean of plant species $\left(G_{S T}=0.29\right.$ and $\left.\square_{S T}=0.35\right)$ found by Nybom and Bartish (2000), and the calculated gene flow $(\mathrm{Nm}=1.224)$ is higher than the mean of plants. Most of the variation was found within populations as has been reported in several studies in forestry species with outcrossing pollination. The AMOVA analysis performed in Costa Rican C. odorata using RAPD (Gilles et al., 1997) also showed that most of the variation was within populations (65.1\%); although this value was much lower than the value found in our study $(86.19 \%)$. On the other hand, $\mathrm{G}_{\text {ST }}$ value gave a different outcome. Most of the variation was between populations (55\%). The authors explained this was due to the presence of two ecotypes (dry type and mesic type) in Costa Rica. The existence of these two ecotypes in Costa Rica has been demonstrated in later studies using cDNA analysis (Cavers et al., 2003a) and morphological traits in an experiment with a common garden (Navarro, Ward \& Hernández, 2002). In fact, two haplotypes (A and B) were found in the Costa Rican populations, each of them corresponding to an ecotype (Cavers et al., 2003a). Haplotype A corresponds to dry ecotype; while haplotype B corresponds to the mesic ecotype. This may also be applicable to the Nicaraguan populations of C. odorata, since the populations from both Western Nicaragua and Northwestern Costa Rica belong to the same haplotype and ecotype (Cavers et al., 2003b). An AMOVA analysis using AFLP showed that most of the variation of Costa Rican C. odorata was between groups $(83.5 \%)$; while a $5.4 \%$ was between populations within groups and $11.2 \%$ was within populations (Cavers et al., 2003a). However, they did a two-level AMOVA separating the groups according to the haplotypes identified through cDNA analysis (haplotypes A and B). The haplotype A, to which the Nicaraguan populations belong (haplotype 3 in Cavers et al. (2003b)), had a similar partition of variation to the one found in our study. They reported values of $79.8 \%$ within populations and $20.2 \%$ between populations; while we found values of $86.19 \%$ within populations and 
13.81\% between populations. A study in Peruvian populations of C. odorata using AFLP (de la Torre et al., 2008) also showed this pattern (72.7\% within populations, $16.5 \%$ between groups, and $10.8 \%$ between populations within groups) reporting a value of $F_{S T}=0.20$. In recent findings, it has been detected that C. odorata has 3 or 4 cryptic species in Mesoamerica (Cavers et al., 2013). So probably, the haplotypes discovered in prior studies (Cavers et al., 2003a; Cavers et al., 2003b) should be elevated to species.

\section{Implications for Conservation and Future Work}

As mentioned before, knowledge of the level and distribution of the genetic variation of a species is necessary to assure the effectiveness and success of any conservation program (Ge, Hong, Wang, Liu \& Zhang, 1998), inasmuch as the evolutionary potential of species and the diversity of their genepools can be maintained for current and future use (Butcher, Glaubitz \& Moran 1999). For that reason, future decisions should be based on quantitative genetic variation as well as patterns of variation revealed from molecular markers. To craft an effective conservation strategy, it is necessary to understand the genetics of the developmental, adaptive and physiological strategies of the populations (Namkoong, 1992), as well as the reproductive biology of the species. Since C. odorata is an obligatory outcrossing species, its fecundity may be influenced by the level of fragmentation and anthropogenic perturbation of their habitats and availability of pollinators flying extensive areas (Hernández Sánchez, 2008). The same author also states that alterations in temperature due to climate change may influence the fecundity of the species by disturbing the pollinator behavior or augmenting fire occurrences.

In the case of the present study, only Western Nicaragua (dry ecotype) populations were taken into account, having most of the variation within populations suggest that sampling from a few populations, for either conservation or breeding activities, may capture a large proportion of the variation of the species in Western Nicaragua. Nevertheless, sampling from a wide range of populations is still advisable.

The presence of the ecotypes reported in Costa Rica is probably applicable for Nicaragua where there are humid ecosystems in the Caribbean Coast. Thus, it is advisable to keep separate both ecotypes for conservation and breeding purpose, especially now that they could be cryptic species (Cavers et al., 2013). A study with more informative markers and including populations of the Caribbean Coast will be necessary to have a better knowledge of the genetic structure of the species in Nicaragua.

Due to the existence of a limited number of individuals of C. odorata, it is necessary to protect the entire existing subpopulations and individuals just as Navarro Pereira (2002) recommended, and taking into consideration minimum distance between trees to ensure gene flow (Hernández Sánchez, 2008). Sáenz-Romero, Snively, and Lindig-Cisneros (2003) proposed "the establishment of a network of in situ forest genetic resources conservation units to protect the genetic variation of P. tecunumanii against immediate-term treats like fragmentation and deforestation". Since C. odorata has an even wider distribution range and also a great pressure as P. tecunumanii, this strategy might be a good approach. In fact, Cavers, Navarro, 
and Lowe (2004) proposed to work in three regions based in the dominant cpDNA lineages that they found in their study with Mesoamerican populations (Cavers et al., 2003b) and also taking into consideration the country boundaries. This regions would be (1) Mexico, Belize and Guatemala; (2) Honduras and Nicaragua; and (3) Costa Rica and Panama. This distribution is based on the fact that the populations sampled from Nicaragua and Honduras are from dry ecotypes. However, humid ecotype populations from Honduras and Nicaragua have to be sampled to have a better delimitation of the conservation units.

\section{Acknowledgments}

We give special thanks to José López and Verónica Díaz who provided valuable help during the fieldwork, and Ben Smith who helped us to edit the grammar of this paper. This research was supported by the Nicaraguan National Institute of Forestry (Instituto Nacional Forestal-INAFOR) through PRORURAL in the Project Marcadores moleculares 2006-2008.

\section{References}

Americas Regional Workshop (Conservation \& Sustainable Management of Trees, Costa Rica, November 1996). (1998). Cedrela odorata. The IUCN Red List of Threatened Species. Version 2014.2. [http://www.iucnredlist.org].

Butcher, P. A., Glaubitz, J. C., \& Moran, G. F. (1999). Applications for microsatellite markers in the domestication and conservation of forest trees. In FAO. FAO: Rome. pp. 34-42.

Cavers, S., Navarro, C., \& Lowe, A. J. (2003a). A combination of molecular markers identifies evolutionarily significant units in Cedrela odorata L. (Meliaceae) in Costa Rica. Conservation Genetics, 4(5), 571-580.

Cavers, S., Navarro, C., \& Lowe, A. J. (2003b). Chloroplast DNA phylogeography reveals colonization history of a Neotropical tree, Cedrela odorata L., in Mesoamerica. Molecular Ecology, 12(6), 1451-1460.

Cavers, S., Navarro, C., \& Lowe, A. J. (2004). Targeting genetic resource conservation in widespread species: a case study of Cedrela odorata L. Forest Ecology and Management, 197(1), 285-294.

Cavers, S., Telford, A., Arenal Cruz, F., Pérez Castañeda, A.J., Valencia, R., Navarro, C., Buonamici, A., Lowe, A.J., \& Vendramin, G.G. (2013). Cryptic species and phylogeographical structure in the tree Cedrela odorata L. throughout the Neotropics. Journal of Biogeography, 40, 732-746.

Cerda Granados, D. A. (2007). Evaluación de la Diversidad Genética de Poblaciones Naturales de Pinus tecunumanii Eguiluz Ë J.P. Perry de Nicaragua Mediante el Uso de Marcadores RAPDs. (Licenciado), Universidad Nacional Autónoma de Nicaragua-León, León, Nicaragua. doi: 10.13140/RG.2.1.3393.3925.

Cordero, J., \& Boshier, D. H. (2003). Árboles de Centroamérica: un manual para extensionistas. Turrialba, Costa Rica: OFI-CATIE.

de la Torre, A., López, C., Yglesias, E., \& Cornelius, J. P. (2008). Genetic (AFLP) diversity of nine Cedrela odorata populations in Madre de Dios, southern 
Peruvian Amazon. Forest Ecology and Management, 255(2), 334-339. doi: 10.1016/j.foreco.2007.09.058

Diaz, V., Muniz, L., \& Ferrer, E. (2001). Random amplified polymorphic DNA and amplified fragment length polymorphism assessment of genetic variation in Nicaraguan populations of Pinus oocarpa. Molecular Ecology, 10(11), 2593-2603.

Excoffier, L., Laval, G., \& Schneider, S. (2005). Arlequin ver. 3.01: An integrated software package for population genetics data analysis. Evol Bioinform Online, 1, 7-50.

Frankham, R., Ballou, J., \& Briscoe, D. (2002). Introduction to conservation genetics. United Kindom: Cambridge University Press.

Ge, S., Hong, D. Y., Wang, H. Q., Liu, Z. Y., \& Zhang, C. M. (1998). Population Genetic Structure and Conservation of an Endangered Conifer, Cathaya argyrophylla (Pinaceae). International Journal of Plant Sciences, 159(2), 351-357.

Gezahgne, A., Coetzee, M. P. A., Wingfield, B. D., Wingfield, M. J., \& Roux, J. (2004). Identification of the Armillaria root rot pathogen in Ethiopian plantations. Forest Pathology, 34(3), 133-145.

Gillies, A. C. M., Cornelius, J. P., Newton, A. C., Navarro, C., Hernández, T. M., \& Wilson, J. (1997). Genetic variation in Costa Rican populations of the tropical timber species Cedrela odorata L., assessed using RAPDs. Molecular Ecology, 6(12), 1133-1145.

Gillies, A. C. M., Navarro, C., Lowe, A. J., Newton, A. C., Hernandez, M., Wilson, J., \& Cornelius, J. P. (1999). Genetic diversity in Mesoamerican populations of mahogany (Swietenia macrophylla), assessed using RAPDs. Heredity, 83(6), 722-732.

González-Rodríguez, A., Arias, D.M., \& Oyama, K. (2005). Genetic variation and differentiation of populations within the Quercus affinis - Quercus lauriana (Fagaceae) complex analyzed with RAPD markers. Canadian Journal of Botany, 83, 155-162.

Hernández Sánchez, L. G. (2008). Genetic diversity and mating system analysis of Cedrela odorata L. (Meliaceae) populations under different human dominated landscapes and primary forests. (PhD) CATIE, Turrialba, Costa Rica.

Holdridge, L. R., Poveda Alvarez, L. J., \& Jiménez Madrigal, Q. (1997). Árboles de Costa Rica (2 ed. Vol. 1). San José, Costa Rica: Centro Científico Tropical.

Jordano, P., \& Godoy, J. A. (2000). RAPD variation and population genetic structure in Prunus mahaleb (Rosaceae), an animal-dispersed tree. Molecular Ecology, 9(9), 1293-1305.

Kimura, M., \& Crow, J. F. (1964). The number of alleles that can be maintained in a finite population. Genetics, 49(4), 725-738.

Lewontin, R. C. (1972). The apportionment of human diversity. In T. Dobzhansky, M. K. Hecht \& W. C. Steere (Eds.), Evolutionary Biology (Vol. 6, pp. 381-398). New York, NY: Meredith Corporation.

Mantel, N. (1967). The detection of disease clustering and a generalized regression approach. Cancer Research, 27(2 Part 1), 209-220.

McDermott, J. M., \& McDonald, B. A. (1993). Gene flow in plant pathosystems. Annual Review of Phytopathology, 31(1), 353-373.

Möller, E. M., Bahnweg, G., Sandermann, H., \& Geiger, H. H. (1992). A simple and efficient protocol for isolation of high molecular weight DNA from 
filamentous fungi, fruit bodies, and infected plant tissues. Nucleic Acids Research, 20(22), 6115-6116.

Namkoong, G. (1992). Biodiversity-issues in genetics, forestry and ethics. The Forest Chronicle, 68(4), 438-443.

Navarro, C., Ward, S., \& Hernández, M. (2002). The tree Cedrela odorata (Meliaceae): a morphologically subdivided species in Costa Rica. Revista de Biologia Tropical, 50(1), 21-30.

Navarro Pereira, C. M. (2002). Genetic resources of Cedrela odorata L. and their efficient use in Mesoamerica. (Ph. D.), University of Helsinki, Helsinki, Finland.

Nei, M. (1973). Analysis of gene diversity in subdivided populations. Proceedings of the National Academy of Sciences, 70(12), 3321-3323.

Nei, M. (1987). Molecular evolutionary genetics. New York, NY: Columbia University Press.

Niembro Rocas, A. (2002). Cedrela odorata L. In J. A. Vozzo (Ed.), Tropical tree seed manual (pp. 386-387). Washington, D.C.: US Department of Agriculture, Forest Service.

Nybom, H., \& Bartish, I. V. (2000). Effects of life history traits and sampling strategies on genetic diversity estimates obtained with RAPD markers in plants. Perspectives in Plant Ecology, Evolution and Systematics, 3(2), 93-114. doi:10.1078/1433-8319-00006.

Pennington, T. D., \& Styles, B. T. (2001). Meliaceae. In W. D. Stevens, C. Ulloa Ulloa, A. Pool \& O. M. Montiel (Eds.), Flora de Nicaragua (Vol. 85). St. Louis, Missouri: Missouri Botanical Garden Press.

Rohlf, F. J. (2005). NTSYS-pc: Numerical Taxonomy and Multivariate Analysis System (Version 2.20). New York, NY: Exeter Software.

Sáenz-Romero, C., Snively, A. E., \& Lindig-Cisneros, R. (2003). Conservation and Restoration of Pine Forest Genetic Resources in Mexico. Silvae Genetica, 52(56), 233-236.

Saitou, N., \& Nei, M. (1987). The neighbor-joining method: a new method for reconstructing phylogenetic trees. Molecular Biology and Evolution, 4(4), 406425.

Sneath, P. H. A., \& Sokal, R. R. (1973). Numerical Taxonomy. San Francisco: WF Freeman and Co.

Soldati, M. C., Fornes, L., Van Zonneveld, M., Thomas, E., \& Zelener, N. (2013). An assessment of the genetic diversity of Cedrela balansae C.DC. (Meliaceae) in Northwestern Argentina by means of combined use of SSR and AFLP molecular markers. Biochemical Systematics and Ecology, 47, 45-55. doi:10.1016/j. bse.2012.10.011.

Webb, D. B., Wood, P. J., \& Smith, J. (1980). A guide to species selection for tropical and sub-tropical plantations. Oxford, UK: Commonwealth Forestry Institute, University of Oxford.

Williams, J. G. K., Kubelik, A. R., Livak, K. J., Rafalski, J. A., \& Tingey, S. V. (1990). DNA polymorphisms amplified by arbitrary primers are useful as genetic markers. Nucleic Acids Research, 18(22), 6531-6535.

Yeh, F. C., \& Yang, R. C. (2000). POPGENE (Version 1.32). Edmonton, AB: University of Alberta and Center for International Forestry. Retrieved from http://www.ualberta.ca/ fyeh/popgene.html 